T. V. Marena

A. M. Peronko

\title{
DEVELOPMENT OF SCIENTIFIC AND METHODICAL APPROACHES TO THE ASSESSMENT OF THE DEBT SECURITY OF UKRAINE
}

The paper considers the concept of country's debt security and studies approaches to assessing its level. The international and Ukrainian official methods of determining the level of debt security are investigated. The absolute indicators of indebtedness and debt ratios are dwelled on. The integral index of debt security of Ukraine for the period of 2007-2018 is calculated according to the Methodic recommendations for calculating the level of economic security of Ukraine adopted in 2013. It is found out that the official method has deficiencies and needs to be improved. The method for calculating the debt security index of Ukraine is developed by expanding the list of debt security components. Using a correlation modeling tool, a system of factor indicators that significantly correlates with the dynamics of the debt security index is determined. To confirm the advisability of proposals towards improving the list of debt security indicators and the importance of the proposed indicators, a multi-factor linear regression model is constructed to characterize the influence of the main factors on the level of debt security of Ukraine.

Key words: public debt, debt security, debt security index, indebtedness, country's solvency, external debt.

DOI 10.34079/2226-2822-2019-9-18-79-86

In terms of dynamic development of financial relations both on the national and international levels, there is a significant increase in demand for financial resources from all countries of the world. An important source of economic development financing is borrowing in the form of domestic and international loans. Inefficient use of borrowed funds often results in countries' inability to meet their debt repayment obligations. The absence of clear debt service repayment schemes leads to the accumulation of domestic and external debt and the inability to repay it in time, which can result in a debt crisis and a decrease in the level of debt security. The state of public debt today is one of the most important criteria for assessing the level of economic, in particular, financial security of the country.

Issues of state debt formation and management as well as the importance of ensuring an optimal level of debt security are widely discussed in actual scientific studies. The general aspects of determining the level and components of national economic security, the criteria and indicators for assessing the financial security of the country are considered in the scientific works of O. Bendesyuk, Z. Varnaliy, S. Onishchenko and other scholars [1, 3]. The theoretical approaches to assessing the debt security of the state based on the consideration of foreign experience and Ukrainian practices are presented in the studies of such Ukrainian scientists as T. Bogdan, O. Vlasyuk, O. Tymoshenko, I. Chui and others [2, 4, 10, 11]. Alongside it, in terms of aggravation of the problems of internal and external debt in Ukraine there is a growing necessity of permanent monitoring of the state of the debt security. In this regard, there is a need to develop and optimize the existing methods of determining the level of debt security. All the facts mentioned above prove the relevance of this study.

The study is aimed at considering the methods of the debt security evaluation in Ukraine and on this basis identifying the ways to improve scientific and methodical approaches towards assessing the level of country's debt security.

Debt security of the state is considered to be an appropriate level of internal and external indebtedness that takes into account the cost of service and efficiency of internal and external borrowing. It must ensure the state's ability to fulfill debt obligations without increasing debt 
burden and eliminating the need of relieving or restructuring of public debt and be enough to meet the overall social and economic needs that do not threaten the state sovereignty and its financial system. Debt security is also characterized as an appropriate level of debt independence, stability and solvency of the country in terms of the impact of risky destabilizing factors of public debt [6]. Proper government policy to ensure the optimal level of internal and external debt security is to be based on the results of monitoring of its current state. The analysis of scientific studies that focus on methods of the debt security assessment, has allowed to identify the following approaches to determine the level of security: determining the level of debt security based on evaluation of its individual indicators; comprehensive assessment of the level of debt security by calculating the integral index of security $[1,2,6,7,8,10,11]$.

The scientific and methodical approach based on assessing individual indicators of the debt security involves monitoring of the main indicators of the indebtedness and the solvency of the country. In international practice, a wide range of relevant indicators is used, but there is no common system of indicators and their marginal values to determine the level of debt security. According to the international experience, the main criterion for assessing debt security is the ratio of public debt to GDP. Other indicators of indebtedness used most often are the following ones: the ratio of the public debt to the state budget revenues; the ratio of the total amount of annual payments on external debt to the state budget revenues; the ratio of the total amount of annual payments on public debt to GDP; and a large number of indicators characterizing the level of external debt. The methodology used by the World Bank anticipates monitoring of the following debt ratios: external debt stocks to exports (\%); external debt stocks to GNI (\%); debt service to exports (\%); short-term to external debt stocks (\%); multilateral to external debt stocks $(\%)$; reserves to external debt stocks (\%) [12].

Evaluation of country's debt security by analyzing of individual indicators of indebtedness and solvency is relatively simple approach, but it has some drawbacks. If various security indicators vary in different directions (some of them indicate an increase in security level and others show security worsening), it may be difficult to conclude what impact will prevail. Moreover, this approach makes it impossible to conduct a comparative analysis of the dynamics of debt security over the years. Taking into account all mentioned above, the scientific and methodic approaches that provide a comprehensive assessment of the level of debt security are considered to be more effective. These techniques are based on the calculation of the integral index of the debt security and allow to determine the change in the level of debt security of the state in dynamics compared to threshold levels.

In Ukraine, there is an official method of calculating the integral index of the debt security, according to which the debt security is a component of financial security of the state. Nowadays, the debt security index is calculated in accordance with the Methodic recommendations for calculating the level of economic security of Ukraine, approved in 2013 [8]. The Methodic recommendations determine the nine components of economic security (including indicators of debt security) and their thresholds levels. According to this document, the debt security indicators in Ukraine include: the ratio of public and publicly guaranteed debt to GDP; the ratio of gross external debt to GDP; weighted average yield of government bonds on the primary market; Index EMBI (Emerging Markets Bond Index) + Ukraine; the ratio of official international reserves to gross external debt [8].

Integral debt security index is defined as:

$$
I_{d e b t}=\sum_{i=1}^{n} d_{i} \times y_{i}
$$

where $\mathrm{I}_{\text {debt }}$ - integrated (aggregate) index of the debt security;

$\mathrm{d}_{\mathrm{i}}$ - weighting factor that determines the degree of contribution of the $\mathrm{i}$-th indicator in the integral index of debt security;

$\mathrm{y}_{\mathrm{i}}$ - normalized score of $\mathrm{i}$-indicator of debt security [8]. 
The method of 2013 has certain advantages over the previous technique adopted in 2007 [7]. According to the actual approach, calculation of the debt security index is somewhat simplified by reducing the number of security indicators from nine to five, while for each of the indicators recommendations for its calculation are given. In addition, the relevant recommendations indicate specific sources for receiving input data on the state of debt. Finally, the new method clearly indicates which debt security indicators are stimulators and which are de-stimulators, and provides a more clear and understandable algorithm for the valuation of the appropriate indicators. On the other hand, reduction in the number of the debt security indicators used for the calculation of the integral index can lead to incomplete account of the factors of the country's debt dependence and solvency formation and decrease the degree of objectivity of the integral index of debt security. Thus, the availability of various methods allows to choose the best approaches for assessing the state of debt security, taking into account the available indicators, the purpose of determining the level of debt security, technical, information and analytical capabilities of the individual or body undertaking the assessment.

In order to assess the debt security comprehensively both absolute and relative indicators can be used. Among the absolute figures, there is total value of public and publicly guaranteed debt, amount of foreign debt, the volumes of external and domestic public debt.

The main relative indicators of indebtedness, which are more informative compared to absolute indicators, are:

- the ratio of total public and publicly guaranteed debt to GDP (\%). The mentioned indicator is a key factor in the debt assessment and development of measures to strengthen debt security, since its critical value is taken into account in the official method for calculating the debt security of Ukraine;

- the level of external debt per capita. It is used in international practice; the level of this indicator is considered critical if it exceeds 200 US dollars [6]. Some European countries that carry out the restructuring of the economy and ensure economic growth by attracting long-term foreign loans have increased the margin of this indicator to 300 US dollars of debt per capita. In Ukraine, this indicator is not used in the official method of debt security calculating;

- the ratio of external debt to the annual exports of goods and services. This indicator shows the country's potential for repayment of foreign debt at the expense of export-oriented industries and sectors of the domestic economy, i.e. it shows the dependence of the national economy on foreign capital inflows;

- the ratio of official international reserves to the volume of gross external debt shows whether the country can use its reserves to repay external debt.

To calculate the integral index of debt security of Ukraine the Methodic recommendations for calculating the level of economic security of Ukraine 2013 is used. Taking into account the lack of data on the dynamics of the EMBI+ Ukraine index in open access, it is proposed to exclude this indicator from the calculation of the debt security index, while the weighting factor of this indicator should be proportionally distributed among other indicators. The calculated integral indices of the level of Ukraine's debt security for the analyzed period tend to decrease, which indicates a deterioration of the situation in the field of debt security (table 1).

Integral index of debt security of Ukraine in 2007-2018

Table 1

\begin{tabular}{|l|l|l|l|l|l|l|l|l|l|l|l|l|l|}
\hline \multicolumn{1}{|c|}{ Indicator } & 2007 & 2008 & 2009 & 2010 & 2011 & 2012 & 2013 & 2014 & 2015 & 2016 & 2017 & $\begin{array}{c}\text { 2018 } \\
\text { weighting } \\
\text { factor }\end{array}$ \\
\hline $\begin{array}{l}\text { 1) The ratio of public } \\
\text { and publicly } \\
\text { guaranteed debt to } \\
\text { GDP, } \%\end{array}$ & 0.2670 & 0.2670 & 0.3080 & 0.2671 & 0.1885 & 0.2567 & 0.1594 & 0.0456 & 0.0403 & 0.0396 & 0.0446 & 0.0526 & 0.2670 \\
\hline
\end{tabular}


ISSN 2518-1394 (Online), ISSN 2226-2822 (Print) ВІСНИК МАРІУПОЛЬСЬКОГО ДЕРЖАВНОГО УНІВЕРСИТЕТУ СЕРІЯ: ЕКОНОМІКА, 2019, ВИП 18

\begin{tabular}{|l|l|l|l|l|l|l|l|l|l|l|l|l|l|l|}
\hline $\begin{array}{l}\text { 2) The ratio of gross } \\
\text { debt to GDP, } \%\end{array}$ & 0.1483 & 0.1451 & 0.0427 & 0.0438 & 0.0494 & 0.0494 & 0.0483 & 0.0393 & 0.0288 & 0.0313 & 0.0366 & 0.0430 & 0.2693 \\
\hline $\begin{array}{l}\text { 3) The average } \\
\text { weighted yield of T- } \\
\text { bills in the primary } \\
\text { market, } \%\end{array}$ & 0.1400 & 0.0413 & 0.0401 & 0.0581 & 0.0852 & 0.0378 & 0.0373 & 0.0364 & 0.0375 & 0.0854 & 0.0563 & 0.0275 & 0.2225 \\
\hline $\begin{array}{l}\text { 4) The ratio of } \\
\text { official international } \\
\text { reserves to gross } \\
\text { debt, } \%\end{array}$ & 0.2940 & 0.0814 & 0.0652 & 0.0768 & 0.0639 & 0.0440 & 0.0347 & 0.0144 & 0.0270 & 0.0333 & 0.0393 & 0.0438 & 0.2412 \\
\hline $\begin{array}{l}\text { Integral index of } \\
\text { debt security }\end{array}$ & 0.6453 & 0.5434 & 0.4585 & 0.4335 & 0.3974 & 0.3977 & 0.2837 & 0.1497 & 0.1282 & 0.1867 & 0.1742 & 0.1669 & 1.0000 \\
\hline
\end{tabular}

Note. Calculated on the basis of data [5, 9]

The integral index of debt security has always been less than $100 \%$, which is rather normal situation. But if up to 2013 the level of debt security was still in optimal range, in subsequent years the index has exceeded the permissible margins. This is especially true for the period of 2014-2015, when the indicator was nearly $15 \%$ and $13 \%$ respectively. This is due to the aggravation of political and economic crisis in Ukraine, the national currency depreciation. The ratio of gross external debt to GDP since 2009 and the amount of public and publicly guaranteed debt to GDP in 2014 exceeded the critical limits. Till 2015 the decrease in the ratio of international reserves to gross debt was observed, but from 2016, in contrast, one can see positive trends. Also, since 2016, the level of debt security is gradually increasing, but remains outside the optimal range.

It should be noted that in general the integral index of debt security, calculated on the basis of the official method, rather informatively reflects the level of indebtedness of Ukraine. At the same time, considering the list of indicators (components) of debt security, the official method does not assess the volume of domestic debt, revenues and expenditures of the public budget, as well as exports of the country, which in some way determines the solvency of the state. Consequently, the method for calculating the integral index of debt security needs to be improved. The study of existing methods for assessing the level of debt security and the practical testing of the official method for calculating the integral index of debt security in Ukraine allow to state that the current method is not ideal one and has certain disadvantages.

An important stage in the assessment of security, on which the information content and objectivity of the obtained integral indexes depends, is the selection of indicators for the list of debt security components. Indicators should be selected on the basis of the principles of representativeness, reliability and availability of information, should most fully characterize each of the sub-indices, taking into account the previous accumulated evaluation experience, developments of domestic and foreign scholars in the field of economic, in particular, debt security, as well as indicators of economic security defined by the international organizations [1]. However, as it was noted above, the absence of data on the dynamics of the EMBI+ Ukraine index in open access violates the requirement for the availability of security indicators. In view of this, it is proposed to exclude this indicator from the list of components of the debt security index (the weighting indicator of the indicator should be proportionally distributed among other indicators).

Another way of improvement of the method for determining the integral index of debt security is the revision of the list of indicators used to calculate it. To identify the indicators that potentially can be included in the calculation of the index, a correlation analysis of the relationship between the calculated integral index of debt security and some indicators of Ukraine's indebtedness and solvency has been carried out. For correlation analysis, several factors were chosen, namely, indicators for calculating debt security index in accordance with the Methodic recommendations for calculating the level of economic security in Ukraine (the ratio of public and publicly guaranteed debt to GDP $\left(\mathrm{x}_{1}\right)$; the ratio of gross external debt to GDP $\left(\mathrm{x}_{2}\right)$; weighted average yield of government bonds on the primary market $\left(\mathrm{x}_{3}\right)$; the ratio of official international reserves to the volume of gross external debt $\left(\mathrm{x}_{4}\right)$ ) and factors that also effect debt security, but are not included in 
the current method (the ratio of external debt to exports $\left(\mathrm{x}_{5}\right)$; the ratio of public and publicly guaranteed debt to state budget revenues $\left(\mathrm{x}_{6}\right)$; level of external debt per capita $\left(\mathrm{x}_{7}\right)$ ).

According to the results of analysis, Ukraine's debt security have the most noticeable correlation with the ratio of public and publicly guaranteed debt to GDP (correlation coefficient is 0.9296), the ratio of official international reserves to gross external debt $(0.9215)$ and the ratio of gross external debt to GDP (-0.82). Among the indicators that are not used in the official method, such factor as the ratio of the public and publicly guaranteed debt to the state budget revenues has the closest reverse relationship with the debt security index (-0.92). The ratio of external debt to export (-0.8337) and the level of external debt per capita $(-0.7333)$ have a significant reverse correlation with the debt security index too. Such factor as weighted average yield of government bonds on the primary market has a correlation of average force (-0.5226). It should be taken into consideration that a very close direct relationship between the factors $\mathrm{x}_{1}$ and $\mathrm{x}_{2}, \mathrm{x}_{2}$ and $\mathrm{x}_{5}, \mathrm{x}_{1}$ and $\mathrm{x}_{6}$ is found out; the tightness of the correlation is approximately identical. Since factors $\mathrm{x}_{1}$ and $\mathrm{x}_{5}$ have a greater correlation with the integral index of debt security, the factor $\mathrm{x}_{2}$ can be eliminated to simplify the method. As soon as factors $\mathrm{x}_{1}$ and $\mathrm{x}_{6}$ have a very close correlation with the debt security index, it is proposed to use both indicators in the method. Thus, taking into account the growth of the national economy dependence on external creditors the use of indicators of external indebtedness within the improved method of the debt security index calculation becomes more significant.

To confirm the advisability of proposals for improving the list of debt security indicators and the significance of the proposed indicators, a multi-factor linear regression model has been developed reflecting the dependence of the debt security index on the selected factor characteristics:

$$
I_{d e b t}=0.7567-0.0091 x_{1}-0.0088 x_{3}+0.0029 x_{4}+0.05652 x_{5}+0.0935 x_{6}-0.00009 x_{7}
$$

The determination coefficient is 0.99 , i.e. the share of variation of factor characteristics accounts for most of the variation of the resultant characteristic compared to the factors that are not considered in the model and influence the change of the resultant characteristic. The proposed multi-factor linear regression equation can be used for additional strengthening of calculations of the integral debt security index, as well as determination of components that have the greatest impact on the level of debt security of the country, when justifying the main directions of reducing the debt burden on the national economy and increasing the solvency of the state.

Thus, in terms of aggravation of the problems of internal and external debt in Ukraine there is a growing necessity of permanent monitoring of the state of debt security. Estimation of the debt security level can be based both on the assessment of its indicators and complex assessment through the calculation of the integral index of debt security. Evaluation of a debt security based on the analysis of indicators of debt is more simple method. However, scientific and methodical approaches that provide a comprehensive assessment of the debt security are more efficient. In Ukraine, the assessment of the debt security is based on the Methodic recommendations for calculating the level of economic security adopted in 2013. Qualitative analysis and practical application of this technique to calculate the debt security index of Ukraine revealed its shortcomings. First, due to the lack of data on the dynamics of the index EMBI+ Ukraine in the open access, which violates the requirement of informational accessibility of security indicators, it is proposed to exclude this indicator from the list of components of the index with a proportional distribution of its weighting among other indicators. Second, taking into account the growing dependence of the national economy on external creditors, the international experience in assessing debt burden, as well as considering the results of the correlation analysis of the relation between the calculated integral debt security index and some indicators of Ukraine's indebtedness and solvency, an improved list of indicators to be used to calculate the debt security index is offered.

It is determined that concurrent use of both approaches towards the assessment of debt security state (monitoring of individual indicators of indebtedness and solvency and calculating the 
integral index of debt security with the help of the improved method) will allow to increase the objectivity of the obtained assessments of the level of debt security of Ukraine and to identify the components that have the greatest impact on it, which is extremely necessary for justification of prior ways of reducing the debt burden on the national economy and raising the solvency of the state. The solution to these problems can be the subject of further research in this area.

\section{Список використаної літератури}

1. Бендесюк О. О. Критерії i індикатори соціально-економічної безпеки / О. О. Бендесюк // Вісник Хмельницького університету. Економічні науки. - 2010. - № 1, T. 2. - C. 7-11 ; Bendesiuk O.O. Kryterii i indykatory sotsialno-ekonomichnoi bezpeky / O. O. Bendesiuk // Visnyk Khmelnytskoho universytetu. Ekonomichni nauky. - 2010. - № 1, T. 2. -S. 7-11.

2. Боргова стійкість державних фінансів / за ред. Т. І. Єфименко, С. А. Срохіна, Т. П. Богдан. - Київ : ДННУ «Акад. фін. управління», 2014. - 712 с. ; Borhova stiikist derzhavnykh finansiv / za red. T. I. Yefymenko, S. A. Yerokhina, T. P. Bohdan. - Kyiv : DNNU «Akad. fin. upravlinnia», 2014. - 712 s.

3. Варналій 3. Сучасні тенденції структурних складових фінансової безпеки України в умовах глобальних перетворень / 3. Варналій, С. Онищенко // Формування ринкової економіки в Україні. - 2016. - Вип. 35, Ч. 1. - С. 75-80 ; Varnalii Z. Suchasni tendentsii strukturnykh skladovykh finansovoi bezpeky Ukrainy $\mathrm{v}$ umovakh hlobalnykh peretvoren / Z. Varnalii, S. Onyshchenko // Formuvannia rynkovoi ekonomiky v Ukraini. - 2016. - Vyp. 35, Ch. 1. - S. 75-80.

4. Власюк О. С. Боргова стійкість як стратегічний напрям підвищення рівня фінансової безпеки [Електронний ресурс] : аналітична доповідь / О. С. Власюк, Л. Г. Шемаєва, Л. П. Лондар. - Київ : НІСД, 2016. - 50 с. - Режим доступу : http://old2.niss.gov.ua/content/articles/files/borg-1fd6c.pdf ; Vlasiuk O.S. Borhova stiikist yak stratehichnyi napriam pidvyshchennia rivnia finansovoi bezpeky [Elektronnyi resurs] : analitychna dopovid / O. Vlasiuk, L. H. Shemaieva, L. P. Londar. - Kyiv : NISD, 2016. - 50 s.- Rezhym dostupu : http://old2.niss.gov.ua/content/articles/files/borg-1fd6c.pdf

5. Державний борг та гарантований державою борг [Електронний ресурс] // Міністерство фінансів України. - Режим доступу : https://mof.gov.ua/uk/derzhavnij-borg-tagarantovanij-derzhavju-borg ; Derzhavnyi borh ta harantovanyi derzhavoiu borh [Elektronnyi resurs] // Ministerstvo finansiv Ukrainy. - Rezhym dostupu : https://mof.gov.ua/uk/derzhavnijborg-ta-garantovanij-derzhavju-borg

6. Котіна Г. Боргова безпека України: оцінка, ризики та перспективи / Г. Котіна, М. Степура, П. Кондро // Схід. - 2017. - № 3. - С. 10-15 ; Kotina H. Borhova bezpeka Ukrainy: otsinka, ryzyky ta perspektyvy / H. Kotina, M. Stepura, P. Kondro // Skhid. - 2017. - № 3. - S. 1015.

7. Про затвердження Методики розрахунку рівня економічної безпеки України [Електронний ресурс] : Наказ Міністерства економіки України від 02.03.2007 p. № 60. Режим доступу : https://zakon.rada.gov.ua/rada/show/v0060665-07 ; Pro zatverdzhennia Metodyky rozrakhunku rivnia ekonomichnoi bezpeky Ukrainy [Elektronnyi resurs] : Nakaz Ministerstva ekonomiky Ukrainy vid 02.03.2007 r. № 60. - Rezhym dostupu : https://zakon.rada.gov.ua/rada/show/v0060665-07

8. Про затвердження Методичних рекомендацій щодо розрахунку рівня економічної безпеки України [Електронний ресурс] : Наказ Міністерства економічного розвитку і торгівлі України від 29 жовтня 2013 р. № 1277. - Режим доступу : https://zakon.rada.gov.ua/rada/show/v1277731-13 ; Pro zatverdzhennia Metodychnykh rekomendatsii shchodo rozrakhunku rivnia ekonomichnoi bezpeky Ukrainy [Elektronnyi resurs] : 
Nakaz Ministerstva ekonomichnoho rozvytku i torhivli Ukrainy vid 29 zhovtnia 2013 r. № 1277. Rezhym dostupu : https://zakon.rada.gov.ua/rada/show/v1277731-13

9. Статистика Національного банку України [Електронний ресурс] // Національний банк України. - Режим доступу : https://www.bank.gov.ua/statistic ; Statystyka Natsionalnoho banku Ukrainy [Elektronnyi resurs] // Natsionalnyi bank Ukrainy. - Rezhym dostupu : https://www.bank.gov.ua/statistic

10. Тимошенко О. В. Європейські критерії оцінювання боргової безпеки / О.В. Тимошенко // Актуальні проблеми економіки. - 2015. - № 7. - С. 366-376 ; Tymoshenko O. V. Yevropeiski kryterii otsiniuvannia borhovoi bezpeky / O.V. Tymoshenko // Aktualni problemy ekonomiky. - 2015. - № 7. - S. 366-376.

11. Чуй I. Методичні підходи до оцінювання боргової безпеки / І. Чуй, О. Мицак // Науковий вісник НЛТУ України. - 2016. - Вип. 26.6. - С. 225-231 ; Chui I. Metodychni pidkhody do otsiniuvannia borhovoi bezpeky / I. Chui, O. Mytsak // Naukovyi visnyk NLTU Ukrainy. - 2016. - Vyp. 26.6. - S. 225-231.

12. International Debt Statistics 2020 [Electronic resource] // World Bank Group, 2019. - 174 p. - Mode of access:

https://openknowledge.worldbank.org/bitstream/handle/10986/32382/9781464814617.pdf

Стаття надійшла до редакції 25.10.2019

\section{T. В. Марена}

А. М. Перонко

\section{РОЗВИТОК НАУКОВО-МЕТОДИЧНИХ ПІДХОДІВ ДО ОЦІНКИ БОРГОВОЇ БЕЗПЕКИ УКРАЇНИ}

Статтю присвячено дослідженню сучасних методик визначення рівня боргової безпеки України і на иій основі ідентифікаиії шляхів удосконалення науково-методичних підходів до оцінки рівня боргової безпеки начіональної економіки. Зазначено, щэо в умовах загострення 8 Україні ситуаціі із внутрішньою та зовнішньою заборгованістю зростає необхідність постійного моніторингу стану боргової безпеки держави. Встановлено, щуо визначення рівня боргової безпеки може здійснюватися на основі як аналізу окремих ї̈ показників, так $i$ комплексної оцінки через розрахунок інтегрального індексу безпеки. При цьому більш ефективними є науково-методичні підходи, щэо дозволяють отримати інтегральну оцінку рівня боргової безпеки.

В Україні розрахунок рівня боргової безпеки здійснюється на основі Методичних рекомендащій щзодо розрахунку рівня економічної безпеки 2013 р. Якісний аналіз та практичне застосування даної методики для розрахунку індексу боргової безпеки України дозволили виявити ї̈ недоліки. По-перше, у зв'язку з відсутністю даних щодо динаміки індексу ЕМВI+ Україна у відкритому доступі, щзо порушує вимогу щзодо інформаційної доступності показників безпеки, запропоновано виключити цей індикатор із переліку складових індексу із пропориійним розподілом його вагового коефіцієнту між іншими індикаторами. По-друге, беручи до уваги зростання залежності національної економіки від зовнішніх кредиторів, світовий досвід очінки боргового навантаження, а також враховуючи результати корелячійного аналізу взаємозв'язку розрахованого інтегрального індексу боргової безпеки з окремими показниками заборгованості та платоспроможності України, запропоновано удосконалений перелік індикаторів, що мають використовуватися для обчислення індексу боргової безпеки. Зокрема, зазначено, щзо при розрахунку інтегрального індексу боргової безпеки доцільно застосовувати у якості індикаторів такі показники, як: відношення обсягу державного та гарантованого державою боргу до ВВП, середньозважена дохідність облігачій внутрішньої державної позики на первинному ринку, відношення офіиійних міжнародних резервів до обсягу валового зовнішнього боргу, відношення зовнішнього боргу до експорту, відношення державного та гарантованого 
державою боргу до доходів державного бюджету, рівень зовнішньої заборгованості на одну особу. Визначено, щуо одночасне застосування методу аналізу окремих індикаторів безпеки та методу розрахунку інтегрального індексу безпеки дозволить підвищити об'єктивність отриманих оцінок рівня боргової безпеки та визначити складові, які мають на неї найбільший вплив, щуо є необхідним для обтрунтування пріоритетних напрямів зменшення боргового навантаження на нащіональну економіку та підвищення платоспроможності держави.

Ключові слова: державний борг, боргова безпека, індекс боргової безпеки, боргове навантаження, платоспроможність

УДК 349.6

Х. С. Мітюшкіна

А. І. Зарагулова

\section{ІНСТИТУЦЙНІ ЗАСАДИ ЕКОЛОГІЧНОГО УПРАВЛІННЯ УКРАЇНИ ТА ПОЛЬЩІ}

До найбільш гострих протиріч, щзо мають нині глобальний характер, відносяться проблеми між суспільством $і$ природою. Суть проблем між суспільством $i$ природою визначається постійно зростаючою потребою суспільного виробництва в природних ресурсах $i$ прогресуючому погіршенні умов життєдіяльності людини. Управління природокористуванням є лише одним із зрізів, або аспектів більш широкої проблеми раціоналізації господарювання, і основним суб'єктом господарювання, на рівні якого повинна вирішуватися ия проблема, є підприємство-природокористувач.

Використання всього спектру інструментів як адміністративного, так і особливо економічного характеру підвищує ефективність державного регулювання в сфері природокористування, і забезпечує досягнення екологічної безпеки регіонального розвитку. Метою екологічного управління є зменшення деструктивного впливу виробничих процесів на навколишнє середовище, зниження ресурсо- та енергоємності продукиіі, загальне підвищення ефективності використання природних ресурсів. Формування ефективного механізму управління природокористуванням в Украӥні потребує дослідження зарубіжного досвіду.

Статтю було присвячено вивченню інститучійних засад екологічного управління України та Польщі. Досліджено особливості польської системи екологічного управління. Виявлено важливі аспекти екологічного управління Польщі, до яких відносять: нормування якості елементів довкілля; нормування якості палива; нормування викидів шкідливих речовин; лічензування виробничої діяльності; планування $i$ поділ території на зони. Проведено порівняння систем управління довкіллям та загальні принципи діяльності держави в галузі навколишнього середовища України й Польщі. Розглянуто ринкові регулятори природокористування, які використовуються в Польщі.

Визначено основні пріоритети охорони довкілля та раціонального використання природних ресурсів в Украӥні. Упорядковано нормативно-правову базу екологічного регулювання за рахунок виділення таких блоків: конституційне, еколого-правове та міжнародне. Існуюча система методів управління природними ресурсами в Україні включає адміністративні, економічні та ринкові методи. В статті систематизовано методи управління природними ресурсами з виокремленням стимулюючих, примусових, підтримуючих та ринкових функцій. Грунтуючись на польському досвіді визначено напрямки вдосконалення екологічного управління в Украӥні.

Ключові слова: природні ресурси, природокористування, державне екологічне управління, механізм управління природними ресурсами, бізнес-адміністрування природокористування. 